\title{
KAJIAN SIFAT FISIOLOGI KERAPU LUMPUR (Epinephe/us tauvina) SEBAGAI DASAR DALAM PENGEMBANGAN TEKNIK TRANSPORTASI HIDUP
}

\author{
Singgih Wibowo"), Th. Dwi Suryaningrum"), dan Bagus Sediadi Bandol Utomo")
}

\begin{abstract}
ABSTRAK
Penelitian mengenai sifat fisiologi ikan kerapu yang meliputi aktivitas, kecepatan respirasi dan metabolisme pada berbagai suhu rendah sebagai dasar pengembangan teknologi transportasi ikan kerapu hidup telah dilakukan. Pengamatan dilakukan dengan cara menurunkan suhu media ikan kerapu secara bertahap dengan kecepatan $5^{\circ} \mathrm{C} / j a m$ dalam kotak respirometer. Aktivitas, respirasi dan metabolisme ikan diamati setiap 30 menit. Hasil penelitian menunjukkan bahwa ikan kerapu lumpur memiliki karakter aktivitas fisik, respirasi, dan metabolisme yang spesifik terhadap perubahan suhu lingkungan. Fase-fase respon fisik, respirasi, dan metabolisme ikan kerapu terhadap suhu dingin dapat dibagi menjadi 6 fase yaitu fase normal (terjadi pada suhu $28^{\circ}-21^{\circ} \mathrm{C}$ ) fase tenang $\left(21^{\circ}-16^{\circ} \mathrm{C}\right.$ ), fase aktivasi atau awal kegelisahan $\left(16^{\circ}-15^{\circ} \mathrm{C}\right)$ fase panik $\left(15^{\circ}-14^{\circ} \mathrm{C}\right)$, fase kehilangan keseimbangan atau awal disorientasi $\left(14^{\circ}-11^{\circ} \mathrm{C}\right)$, dan fase pingsan $\left(11^{\circ}-9^{\circ} \mathrm{C}\right)$. Pola respirasi dan metabolisme ikan kerapu lumpur cenderung makin rendah dengan makin rendahnya suhu. Pada awal penurunan suhu terjadi aktivasi respirasi dan metabolisme (hingga suhu $21^{\circ} \mathrm{C}$ ) diikuti dengan penurunan respirasi dan metabolisme yang tajam (hingga suhu $19^{\circ} \mathrm{C}$ ), akan tetapi respirasi dan metabolisme meningkat kembali bersamaan berlangsungnya fase kepanikan $\left(15^{\circ} \mathrm{C}\right)$, kemudian terus menurun bersamaan dengan penurunan suhu hingga $9^{\circ} \mathrm{C}$. Titik-titik krusial yang berpeluang untuk digunakan dalam transportasi adalah suhu $21^{\circ}$, $19^{\circ}$ dan $17^{\circ} \mathrm{C}$ tergantung dari metoda dan sistem transportasi yang digunakan.
\end{abstract}

\section{ABSTRACT: Study on Physiological Characteristics of Grouper as the Basic for the Development of its Live Transportation. By: Singgih Wibowo, Th. Dwi Suryaningrum, and Bagus Sediadi Bandol Utomo}

A study of physiological characteristics consisting of physical activity, respiration rate, as well as metabolism rate of grouper were conducted to get the basic data for development of its transportation techniques. Observation of the physical activity, respiration and metabolism rates were done every 30 minutes during a gradual decreament of the temperature of seawater media in respirometer box. The result revealed that grouper showed a spesific physical activity, respiration rate and metabolism rate related to temperature changes. This spesific characteristics could be grouped into 6 phases $i$. e normal phase $\left(\left(28-21^{\circ} \mathrm{C}\right)\right.$, calm phase $\left(21-16^{\circ} \mathrm{C}\right)$, activation phase $\left(16-15^{\circ} \mathrm{C}\right)$, panic phase $\left(15-14^{\circ} \mathrm{C}\right)$, disorientation phase (14$11^{\circ} \mathrm{C}$ ) and unconsious phase $\left(11-9^{\circ} \mathrm{C}\right)$. The transportation and metabolism rate tended to decrease with the lowering of the temperature. As the initial of temperature decreased (up to $21^{\circ} \mathrm{C}$ ) the rate of respiration and metabolism increased but then decreased sharply during the temperature decreased up to $19^{\circ} \mathrm{C}$. Surprisingly at lower temperature (up to $15^{\circ} \mathrm{C}$ ) the respiration and metabolism rate again raised which presumably due to the fish coming into a panic phase. At subsequent lowerred temperature, the respiration and metabolism rate were again decreased gradually. According to the result it is assumed that the critical temperature that could be used in the transportation of live grouper were 21,19 and $17^{\circ} \mathrm{C}$ depending on the transportation methods.

KEYWORDS: physiological characteristics, grouper, respiration, metabolism, immotilization.

Peneliti pada Pusat Riset Pengolahan Produk dan Sosial Ekonomi Kelautan dan Perikanan 


\section{PENDAHULUAN}

Dewasa ini permintaan komoditas perikanan di pasar internasional, cenderung mengalami pergeseran dari ikan bentuk beku ke bentuk segar, kemudian ke bentuk hidup. Pergeseran pola permintaan ini tampaknya seirama dengan peningkatan kesejahteraan, pendidikan, dan kesadaran akan hidup sehat.

Permintaan ikan konsumsi terutama jenis kerapu dalam bentuk hidup cukup tinggi, sebagai contoh kebutuhan pasar di Hongkong sekitar 5.000-6.000 ton/th, Cina 15.000 ton/th, Taiwan 1.200-5.000 ton/th dan Singapura 400-500 ton/th (Pawiro, 1999). Peluang pasar tersebut di atas perlu dimanfaatkan, sehingga upaya-upaya untuk mendorong pemanfaatan peluang ini perlu mendapatkan prioritas, di antaranya adalah dukungan berupa teknologi penanganan dan transportasi ikan kerapu hidup yang ekonomis, efektif, dan efisien.

Ada dua cara transportasi ikan kerapu hidup yaitu transportasi hidup dengan sistem terbuka dengan menggunakan wadah yang diberi aerasi dan transportasi sistem tertutup dengan menggunakan kantong plastik yang diberi oksigen. Transportasi hidup pada dasarnya selalu menggunakan metode imotilisasi. Imotilisasi dapat dilakukan dengan menggunakan suhu rendah atau senyawa antimetabolik kimia atau alami seperti biji karet, buah pala, rumput laut (Wibowo, 1993).

Imotilisasi dengan suhu rendah dirasakan paling aman, ekonomis dan efektif. Imotilisasi dengan suhu rendah dilakukan dengan cara menurunkan suhu media sampai suhu tertentu saat tingkat aktivitas, respirasi dan metabolisme sangat rendah atau pada kondisi basal, sehingga ikan kerapu dapat diangkut dalam waktu yang lama dengan sintasan yang tinggi. Informasi tentang pengaruh suhu rendah terhadap aktivitas, respirasi, dan metabolisme ikan kerapu sejauh ini masih belum tersedia sehingga tidak mudah untuk menentukan kondisi yang sesuai untuk transportasi hidup ikan tersebut. Penelitian ini ditujukan untuk mempelajari sifat fisiobiologis ikan kerapu yang hasilnya dapat digunakan sebagai informasi dasar untuk transportasi hidup. Penelitian ditekankan untuk mempelajari pola respirasi dan metabolisme ikan kerapu pada berbagai suhu.

Berdasarkan pola ini diharapkan dapat diambil indikasi adanya titik-titik suhu krusial yang berkaitan dengan respirasi dan metabolisme ikan yang dapat digunakan untuk keperluan transportasi ikan kerapu hidup dengan sistem basah.

\section{BAHAN DAN METODE}

\section{Bahan}

Bahan utama yang digunakan dalam penelitian ini adalah ikan kerapu lumpur (Epinephelus tauvina) yang diambil dari daerah Serang, Banten. Ikan yang digunakan dipilih yang dalam kondisi sehat, tidak cacat, dan berukuran sekitar 3 ekor per kilogram (bobot rata-rata $336,07 \pm 25,43$ g/ekor, panjang total $28,27 \mathrm{~cm} \pm 1,11 \mathrm{~cm} /$ ekor). Ikan kerapu ditampung untuk dibugarkan, dan dipuasakan sebelum digunakan untuk percobaan.

Bahan bantu yang digunakan adalah es air laut, dan air laut (salinitas 33 ppt.) yang telah disaring dengan menggunakan filter bertekanan. Sebelum digunakan untuk penelitian, air disaring dengan saringan plankton ukuran 100 mesh.

\section{Peralatan}

Peralatan yang digunakan dalam penelitian ini meliputi peralatan untuk percobaan, pengamatan dan analisis. Peralatan untuk percobaan adalah respirometer hasil disain dan rakitan Pusat Riset Pengolahan Produk dan Sosial Ekonomi Kelautan dan Perikanan. Respirometer ini terbuat dari bahan akrilik berukuran $60 \times 60 \times 40 \mathrm{~cm}$ dilengkapi dengan pompa sirkulator, aerator, oksimeter, termometer serta diberi outlet dan inlet untuk memasukkan dan mengeluarkan air. Peralatan untuk pengamatan dan analisis adalah timbangan (Lion Star $2 \mathrm{~kg}$ ), termo-meter (Kane May KM 1242, Thermoline), pencatat waktu (timer), salinometer (Atago S Miln), oksimeter (YSI Model 58), spektro-fotometer (Spectronic 21)., dan peralatan analisis mutu air lainnya.

\section{Metode Penelitian}

Tingkat respirasi ikan kerapu pada berbagai suhu diamati berdasarkan tingkat penurunan oksigen terlarut di dalam air dalam respirometer per satuan waktu. Sedangkan tingkat metabolisme dilihat dari peningkatan kandungan metabolit air dalam respirometer per satuan waktu. Percobaan dilakukan dengan cara memasukkan 5 ekor ikan kerapu 
ke dalam kotak respirometer yang telah diisi air laut sampai penuh kemudian pompa sirkulator dan aerator dioperasikan dengan kecepatan kuat. Suhu air kemudian diturunkan secara bertahap dengan mengalirkan air dingin (suhu $0^{\circ} \mathrm{C}$ ) ke dalam kotak respirometer. Aliran air dingin diatur sedemikian rupa sehingga terjadi penurunan suhu dengan kecepatan $5^{\circ} \mathrm{C} / \mathrm{jam}$ atau $0.4^{\circ} \mathrm{C} / 5$ menit (Berka, 1986). Pengamatan terhadap respirasi, metabolisme dan aktivitas ikan kerapu diamati setiap $\mathbf{3 0}$ menit.

Pengamatan respirasi dan metabolisme ikan kerapu dilakukan sebagai berikut : setelah suhu air diturunkan perlahan dalam waktu 30 menit, aerasi dihentikan, gelembung udara di dalam respirometer dihilangkan dan respirometer ditutup rapat sehingga tidak terjadi kontak antara udara dengan air atau ikan. Suhu, oksigen terlarut dan kandungan metabolit di dalam air diamati selama 15 menit dengan selang waktu $0,5,10$ dan 15 menit. Di samping itu juga diamati aktivitas ikan kerapu dengan mencatat gerakangerakan yang terjadi selama pengamatan. Setelah selesai pengamatan respirometer dibuka kembali, sirkulator dan aerator dihidupkan serta penambahan air dingin untuk menurunkan suhu dilanjutkan.

Demikian seterusnya perlakuan dan pengamatan dilakukan sampai ikan pingsan. Tingkat respirasi ikan dihitung dari selisih antara tingkat kelarutan oksigen pada saat aerasi dihentikan dengan kelarutan oksigen setelah 15 menit, dibagi berat ikan per satuan waktu. Sedangkan metabolit ikan yang diamati adalah kadar $\mathrm{CO}_{2}, \mathrm{NH}_{3}$ dan $\mathrm{NO}_{2}$ dari contoh air yang keluar dari outlet pada respirometer. Percobaan dilakukan dengan dua kali ulangan.

\section{HASIL DAN PEMBAHASAN}

\section{Pengaruh Suhu Rendah Terhadap Aktivitas Ikan Kerapu}

Aktivitas ikan kerapu pada berbagai suhu rendah dapat dilihat pada Tabel 1. Akibat penurunan suhu media yang makin rendah, ikan memberikan respon dalam beberapa fase. Pada suhu sampai $21^{\circ} \mathrm{C}$ aktivitas ikan masih normal. Pada suhu $21-19^{\circ} \mathrm{C}$ ikan memasuki fase kedua yaitu mulai memasuki fase tenang. Pada suhu $19-17^{\circ} \mathrm{C}$ ikan berada dalam fase tenang dan fase tenang ini dapat berlangsung hingga suhu $16^{\circ} \mathrm{C}$. Fase tenang ini kemudian diikuti dengan fase aktivasi yang menjadi awal kegelisahan yang terjadi pada suhu $16-15^{\circ} \mathrm{C}$. Fase berikutnya adalah fase panik yang terjadi pada suhu $14.8-14^{\circ} \mathrm{C}$. Setelah mengalami kepanikan, ikan kemudian kehilangan keseimbangan dan terjadi disorientasi sehingga ikan roboh $\left(14-11^{\circ} \mathrm{C}\right)$. Pada suhu di bawah $11^{\circ} \mathrm{C}$ ikan memasuki fase menjelang pingsan atau bahkan dapat dikategorikan pingsan.

Dari hasil di atas tampak bahwa terdapat titik-titik krusial yaitu pada suhu sekitar 21, $19,17,15,14,11,9^{\circ} \mathrm{C}$ dan di bawah suhu $4^{\circ} \mathrm{C}$ yang muncul pada respon ikan kerapu akibat turunnya suhu lingkungan. Pada titik-titik krusial ini terjadi perubahan aktivitas dan respon ikan kerapu yang nyata, yang diharapkan merupakan momen yang tepat saat ikan menunjukkan kemampuan yang tinggi dalam mempertahankan hidupnya. Karena pada dasarnya, dalam kondisi krusial makhluk hidup cenderung menunjukkan kemampuan yang tinggi dalam mempertahankan kelangsungan hidupnya .

Fase-fase yang terjadi pada ikan kerapu lumpur ini tampaknya memiliki pola serupa dengan yang terjadi pada udang windu tambak meskipun masing-masing berlangsung pada titik suhu berbeda (Soekarto dan Wibowo, 1993; Suparno et al., 1994; Wibowo et al., 1995). Kesamaan yang tampak adalah adanya fase normal, fase tenang, fase gelisah, fase roboh, fase panik, fase kehilangan kesimbangan, dan fase pingsan. Persamaan yang paling mencolok pada ikan kerapu maupun udang windu tambak adalah bahwa setelah diawali dengan kegelisahan, kedua jenis ikan tersebut mengalami kepanikan yang kemudian langsung diikuti dengan kehilangan keseimbangan.

Dari hasil pengamatan di atas dapat ditarik kesimpulan bahwa berdasarkan karakteristik aktivitas ikan pada suhu rendah, suhu yang berpeluang untuk digunakan sebagai suhu imotil dalam transportasi hidup adalah suhu $21-9^{\circ} \mathrm{C}$. Di atas atau di bawah suhu tersebut resiko kematian selama transportasi di khawatirkan cukup tinggi. Makin rendah suhu tentu membutuhkan enersi cukup besar baik untuk mencapai maupun untuk mempertahankan suhu tersebut yang berarti juga membutuhkan biaya besar. Sementara itu, untuk transportasi ikan hidup dengan sistem basah (menggunakan media air) dapat menggunakan suhu yang lebih tinggi, karena transportasi sistem basah dapat dilakukan pada saat ikan berada pada fase tenang (21- 
$15^{\circ} \mathrm{C}$ ). Hal ini lebih menguntungkan jika dilihat dari aspek teknis dan ekonomisnya.

\section{Pengaruh Suhu Rendah Terhadap Respirasi Ikan Kerapu}

Respirasi ikan kerapu pada berbagai suhu rendah disajikan pada Gambar 1 dan 2. Gambar 1 menunjukkan pola konsumsi oksigen $\left(\mathrm{mgO}_{2} / \mathrm{kg}\right.$ berat ikan/jam) dan Gambar 2 menunjukkan pola produksi $\mathrm{CO}_{2}$ (ppm) hasil respirasi. Pola respirasi ikan kerapu lumpur cenderung berfluktuasi dengan makin turunnya suhu. Pada awal penurunan suhu terjadi peningkatan konsumsi oksigen hingga suhu mencapai $21^{\circ} \mathrm{C}$ yang diikuti penurunan konsumsi $\mathrm{O}_{2}$ yang tajam hingga suhu mencapai $19^{\circ} \mathrm{C}$, kemudian konsumsi $\mathrm{O}_{2}$ meningkat kembali hingga mencapai suhu $15^{\circ} \mathrm{C}$. Setelah itu konsumsi $\mathrm{O}_{2}$ menurun dengan turunnya suhu, dan mulai $13^{\circ} \mathrm{C}$ konsumsi $\mathrm{O}_{2}$ relatif stabil hingga suhu $11^{\circ} \mathrm{C}$. Pada suhu di bawah $11^{\circ} \mathrm{C}$ konsumsi $\mathrm{O}_{2}$ ikan terus turun. Pola konsumsi $\mathrm{O}_{2}$ yang berfluktuasi ini ternyata telah menyebabkan berfluktuasinya senyawa hasil respirasi, yaitu $\mathrm{CO}_{2}$ (Jhingran and Pullin, 1985) yang polanya sangat mirip sekali (Gambar 2). Ketika konsumsi oksigen meningkat, produksi $\mathrm{CO}_{2}$ pun meningkat (Jhingran and Pullin, 1985; Berka, 1986). Hasil ini menunjukkan bahwa penurunan suhu menyebabkan pola respirasi ikan kerapu hidup berfluktuasi dengan kecenderungan makin rendah suhu makin rendah tingkat respirasinya sebagaimana ditunjukkan kurva regresi liniernya (Gambar 1).

Pada awal terjadinya penurunan suhu terjadi peningkatan kecepatan respirasi ikan kerapu yang mencapai titik tertinggi $(2,199 \mathrm{mg}$ $\mathrm{O}_{2} / \mathrm{kg}$ berat ikan/jam) pada suhu $21^{\circ} \mathrm{C}$. Hingga suhu tersebut ikan masih dalam katagori normal (Tabel 1). Penurunan suhu yang dapat menekan respirasi (Fry and Norris, 1962; Huet, 1972; Suseno, 1985; Berka, 1986; Basyarie, 1990; Muchari, 1990; Praseno, 1990) pada tahap ini belum terjadi. Penurunan suhu sampai $21^{\circ} \mathrm{C}$ ternyata masih belum mempengaruhi respirasi maupun aktivitas kerapu, tetapi justru menyebabkan aktivasi respirasi. Hal ini mungkin disebabkan karena ikan kerapu merupakan ikan demersal yang hidup di perairan dalam yang suhunya makin rendah dengan makin dalamnya perairan (Chua and Teng, 1980). Di habitatnya di alam kerapu biasanya hidup dengan suhu lingkungan sekitar $25-21^{\circ} \mathrm{C}$. Karena itu, penurunan suhu hingga $21^{\circ} \mathrm{C}$ tidak menyebabkan penurunan respirasi tetapi justru menyebabkan peningkatan respirasi karena ikan kerapu seolah hidup di dalam habitat aslinya sehingga menyebabkan terjadinya aktivasi respirasi ikan.

Kemampuan penurunan suhu dalam menekan respirasi dan aktivitas ikan kerapu (Fry and Norris, 1962; Huet, 1972; Suseno, 1985; Berka, 1986; Basyarie, 1990; Muchari, 1990; Praseno, 1990) mulai tampak setelah suhu di bawah $21^{\circ} \mathrm{C}$ yaitu respirasi turun tajam hingga mencapai titik terendah pada sekitar $19^{\circ} \mathrm{C}\left(1,339 \mathrm{mg} \mathrm{O} \mathrm{O}_{2} / \mathrm{kg}\right.$ berat ikan/jam). Jika dikaitkan dengan aktivitasnya, penurunan respirasi ini tampaknya berhubungan dengan makin tenangnya ikan kerapu (Tabel 1). sehingga oksigen yang dikonsumsi pun jauh berkurang. Ketika suhu mencapai $17^{\circ} \mathrm{C}$ (ikan kerapu masih dalam kondisi tenang) respirasinya tidak jauh berbeda, yaitu 1,625 $\mathrm{mg} \mathrm{O}_{2} / \mathrm{kg}$ berat ikan/jam.

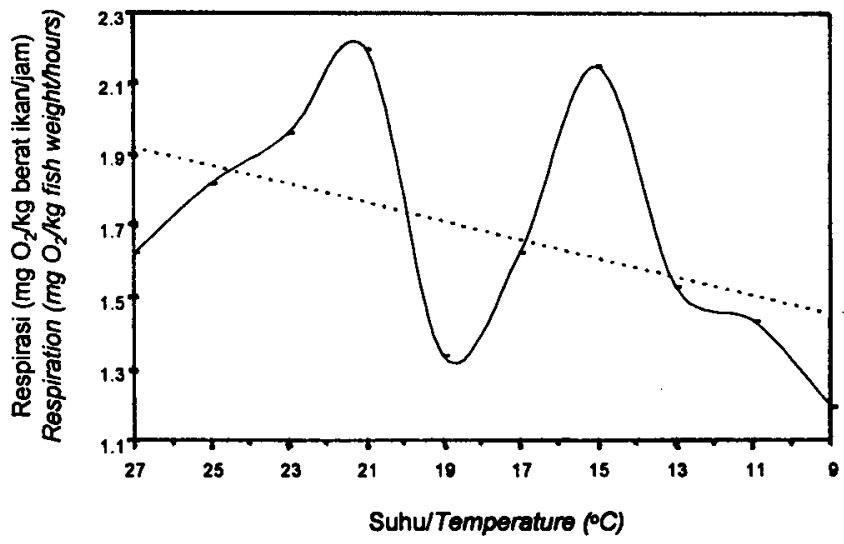

Gambar 1. Pola konsumsi oksigen ikan kerapu hidup pada berbagai suhu Figure 1. Oxygen consumption patterm of grouper at various temperatures 
Ketika suhu berada di bawah $19^{\circ} \mathrm{C}$, respirasi ikan kerapu meningkat cukup tajam hingga suhu sekitar $15^{\circ} \mathrm{C}\left(2,151 \mathrm{mg} \mathrm{O} \mathrm{O}_{2} / \mathrm{kg}\right.$ berat ikan/jam). Peningkatan respirasi ini tampaknya disebabkan karena ikan kerapu mulai gelisah, sering bangkit dari dasar dan berenang agak cepat yang bahkan beberapa di antaranya memuncak menjadi panik.

Peningkatan aktivitas ini tentunya membutuhkan lebih banyak oksigen sehingga respirasi meningkat. Pada tahap berikutnya, meskipun ikan kerapu masih dalam fase panik (suhu $14^{\circ} \mathrm{C}$ ) akan tetapi tingkat respirasinya mulai turun hingga suhu mencapai $13^{\circ} \mathrm{C}$ $\left(1,530 \quad \mathrm{mgO}_{2} / \mathrm{kg}\right.$ berat ikan/jam) dan cenderung stabil hingga suhu $11^{\circ} \mathrm{C}$. Penurunan respirasi ini tampaknya disebabkan sebagian ikan sudah melewati fase panik, dan bahkan mulai ada yang roboh sehingga kebutuhan oksigen pun merosot tajam.

Dari hasil ini, tampaknya fase panik merupakan titik balik bagi aktivitas maupun respirasi ikan kerapu seperti yang terjadi pada udang windu tambak (Soekarto dan Wibowo, 1993; Suparno et al., 1994; Wibowo et al., 1995). Pada udang windu, setelah panik udang pun roboh. Ketika itu pula terjadi penurunan tingkat respirasi yang tajam. Pada ikan kerapu, setelah mengalami kepanikan

Tabel 1. Pola aktivitas ikan kerapu lumpur pada berbagai suhu (kecepatan penurunan suhu $5^{\circ} \mathrm{C} / \mathrm{jam}$ )

Table 1. Grouper activity pattern at various temperatures (temperature decreament rate $5^{\circ} \mathrm{C} / \mathrm{hr}$ )

\begin{tabular}{|c|c|c|c|}
\hline No. & $\begin{array}{c}\text { Suhu }\left({ }^{\circ} \mathrm{C}\right) \\
\text { Temperature }\left({ }^{\circ} \mathrm{C}\right)\end{array}$ & $\begin{array}{l}\text { Aktivitas Kerapu } \\
\text { Grouper Activity }\end{array}$ & $\begin{array}{l}\text { Kriteria } \\
\text { Criteria }\end{array}$ \\
\hline 1 & $28,2-21,3$ & $\begin{array}{l}\text { Ikan tenang di dasar, sesekali berenang perlahan, tubuh } \\
\text { tegak, gerakan katup insang perlahan dan teratur, } \\
\text { responsif terhadap gerakan di luar akuarium, sangat } \\
\text { responsif terhadap sentuhan perlahan. } \\
\text { Fish stayed calm on the bottom, moving slowly from } \\
\text { time to time, gills moved regularly, very responsive to a } \\
\text { moving object outside the water and very responsive to } \\
\text { a touch. }\end{array}$ & $\begin{array}{l}\text { Normal } \\
\text { Normal }\end{array}$ \\
\hline 2 & $20,9-18,6$ & $\begin{array}{l}\text { Aktivitas ikan mulai berkurang dan cenderung diam di } \\
\text { dasar. Respon terhadap gerakan di luar mulai } \\
\text { berkurang, ikan lebih mudah dipegang. } \\
\text { Fish activity decreased, tended to stay on the bottom } \\
\text { but less responsive to moving objects. Fish were } \\
\text { relatively easy to catch. }\end{array}$ & $\begin{array}{l}\text { Mulai Tenang } \\
\text { Calm }\end{array}$ \\
\hline 3 & $18,6-17,0$ & $\begin{array}{l}\text { Aktivitas ikan tidak banyak berubah, tubuh mulai miring } \\
\text { saat berenang dan sirip punggung mulai meregang } \\
\text { (kemudian normal). Respon terhadap gerakan di luar } \\
\text { melemah dan lebih tenang saat dipegang. } \\
\text { Fish activity did not change much, less stable } \\
\text { movement, dorsal fins stretched less responsive to } \\
\text { moving objects. Fish stayed calm when taken. }\end{array}$ & $\begin{array}{l}\text { Tenang } \\
\text { Calm }\end{array}$ \\
\hline 4 & $17,0-15,6$ & $\begin{array}{l}\text { Ikan lebih tenang dan cenderung diam di dasar, } \\
\text { sesekali berenang (tubuh miring), sirip punggung } \\
\text { meregang, warna mulai berubah (memucat dan putih), } \\
\text { gerakan katup insang mulai lemah, respon terhadap } \\
\text { gerakan di luar lemah, respon sentuhan dengan } \\
\text { gerakan mengejut. } \\
\text { Fish stayed calm on the bottom and immobile, moving } \\
\text { slowly from time to time, discoloration on the surface of } \\
\text { the body, gills moved weakly. }\end{array}$ & $\begin{array}{l}\text { Tenang } \\
\text { Calm }\end{array}$ \\
\hline 5 & $15,6-14,8$ & $\begin{array}{l}\text { Ikan mulai sering bangkit dari dasar dan berenang agak } \\
\text { cepat dengan sirip punggung meregang. Gerakan ikan } \\
\text { mengarah ke kegelisahan. Pada beberapa kasus, } \\
\text { setelah kegelisahan memuncak ikan panik. } \\
\text { Fish were still calm with uncontrolable movement from } \\
\text { time to time. Dorsal fins stretched. }\end{array}$ & $\begin{array}{c}\text { Aktivasi, awal } \\
\text { gelisah } \\
\text { Uncontrolable }\end{array}$ \\
\hline
\end{tabular}


Tabel 1. Pola aktivitas ikan kerapu lumpur pada berbagai suhu (kecepatan penurunan suhu $5^{\circ} \mathrm{C} / \mathrm{jam}$ ) (lanjutan)

Table 1. Grouper activity pattern at various temperatures (temperature decreament rate $5^{\circ} \mathrm{C} / \mathrm{hr}$ ). (Continued)

\begin{tabular}{|c|c|c|c|}
\hline No. & $\begin{array}{c}\text { Suhu }\left({ }^{\circ} \mathrm{C}\right) \\
\text { Temperature }\left({ }^{\circ} \mathrm{C}\right)\end{array}$ & $\begin{array}{l}\text { Aktivitas Kerapu } \\
\text { Grouper Activity }\end{array}$ & $\begin{array}{l}\text { Kriteria } \\
\text { Criteria }\end{array}$ \\
\hline 6 & $14,8-14,0$ & $\begin{array}{l}\text { Ikan gelisah, berenang cepat, tubuh miring, sirip } \\
\text { meregang (kemudian tenang kembali), kegelisahan } \\
\text { memuncak dan ikan panik. Ketika panik katup insang dan } \\
\text { mulut membuka lebar. Setelah panik ikan tenang kembali, } \\
\text { gerakan katup insang melemah, hampir tidak } \\
\text { memberikan respon terhadap gerakan di luar dan } \\
\text { sentuhan. } \\
\text { Fish were not longer calm with uncontrolable movement } \\
\text { from time to time. Dorsal fins stretched. Gills and mouth } \\
\text { opened widely and then gills closed and moved very } \\
\text { weakly but no respons to moving objects and touch. }\end{array}$ & $\begin{array}{c}\text { Gelisah, panik } \\
\text { Panick }\end{array}$ \\
\hline 7 & $13,6-11,2$ & $\begin{array}{l}\text { Ikan mulai kehilangan keseimbangan, bergerak dengan } \\
\text { posisi tubuh agak miring dan mendongak ke atas, mulut } \\
\text { ke atas dengan bergerak-gerak cepat dan mulai tidak } \\
\text { teratur, gerakan-gerakan sirip cepat, kemudian ikan } \\
\text { roboh dan rebah di dasar, respon terhadap rangsangan } \\
\text { luar dan sentuhan cenderung instingtif. } \\
\text { Fish lost its balance, with uncontrolable movement from } \\
\text { time to time. Dorsal fins stretched, fins moved very } \\
\text { rapidly and then fell down on the bottom. No more } \\
\text { respons when touched. }\end{array}$ & $\begin{array}{c}\text { Awal disorientasi, } \\
\text { panik, rebah } \\
\text { Disorientation }\end{array}$ \\
\hline 8 & $11,0-9,2$ & $\begin{array}{l}\text { Ikan kehilangan keseimbangan, roboh atau bergerak } \\
\text { dengan tubuh rebah dan kejang (kaku), seluruh anggota } \\
\text { tubuh mengejang, katup insang membuka lebar, pola } \\
\text { warna melintang tubuh hilang, tidak memberikan respon. } \\
\text { lkan bergerak tidak terkendali dan posisi tubuh terbalik } \\
\text { dengan perut di atas tanpa gerakan, kemudian ikan } \\
\text { roboh di dasar dengan gerakan-gerakan sangat jarang } \\
\text { dan sangat lemah. } \\
\text { Fish lost its balance, with uncontrolable movement from } \\
\text { time to time while the whole body stretched. Gills opened } \\
\text { widely. Dorsal fins stretched, fins moved very rapidly and } \\
\text { then fell down on the bottom. No more respons when } \\
\text { touched. }\end{array}$ & $\begin{array}{c}\text { Hampir pingsan } \\
\text { Almost } \\
\text { unconcious }\end{array}$ \\
\hline 9 & $8,8-4,0$ & $\begin{array}{l}\text { Tubuh ikan kaku, berlendir, tidak ada gerakan sama } \\
\text { sekali, tidak memberikan respon terhadap sentuhan atau } \\
\text { bila diangkat dari air, hanya terdapat gerakan sangat } \\
\text { lemah pada katup insang. } \\
\text { Fish body became rigid, slimmy, and totally collaps and } \\
\text { unconcious. No respons when taken outside the water } \\
\text { only gill's membrane moved very weakly. }\end{array}$ & $\begin{array}{c}\text { Pingsan } \\
\text { Unconcious }\end{array}$ \\
\hline
\end{tabular}

ikan tenang kembali dan bahkan rebah serta hanya memberikan respon instingtif terhadap rangsangan luar dan sentuhan (Tabel 1). Kondisi inilah yang menyebabkan respirasi turun tajam. Setelah semua ikan rebah dan hampir pingsan atau pingsan, respirasi ikan turun kembali hingga mencapai $1,195 \mathrm{mg}$ $\mathrm{O}_{2} / \mathrm{kg}$ berat ikan/jam pada suhu $9^{\circ} \mathrm{C}$ (Gambar 1).
Jika diamati hasil tersebut di atas, dapat diambil beberapa titik suhu yang berpeluang untuk keperluan transportasi ikan kerapu hidup. Kisaran suhu $21^{\circ}-17^{\circ} \mathrm{C}$ tampaknya memiliki peluang besar untuk digunakan dalam trasportasi ikan kerapu hidup dengan sistem basah (Mc Farland dalam Djajadipoera, 1988). Pada kisaran suhu tersebut ikan sudah cukup tenang dan mudah 
ditangani untuk dikemas sementara respirasinya cukup rendah. Untuk keperluan transportasi sistem kering, karena ikan ditempatkan di luar habitat hidupnya, mungkin diperlukan kondisi ikan yang jauh lebih tenang dan respirasi rendah, yaitu setelah ikan melewati fase panik.

\section{Pengaruh Suhu Rendah Terhadap Metabolisme Ikan Kerapu}

Untuk mempelajari pengaruh suhu rendah terhadap metabolisme ikan kerapu, dilakukan pengamatan terhadap produksi metabolitnya, yaitu $\mathrm{NH}_{3}$ dan $\mathrm{NO}_{2}$. Hasilnya seperti yang disajikan di dalam Gambar 3 dan 4. Gambar 3 menunjukkan pola perubahan produksi $\mathrm{NH}_{3}$ dan Gambar 4 menunjukan pola produksi $\mathrm{NO}_{2}$. Dari Gambar 3 dan 4 dapat dilihat bahwa pola produksi metabolit $\left(\mathrm{NH}_{3}\right.$ dan $\left.\mathrm{NO}_{2}\right)$ ikan kerapu cenderung makin rendah dengan makin rendahnya suhu namun dengan pola yang berfluktuasi. Perubahan produksi metabolit $\left(\mathrm{NH}_{3}\right.$ dan $\left.\mathrm{NO}_{2}\right)$ ini ternyata sangat serupa polanya dengan pola respirasi maupun aktivitas ikan kerapu (Gambar 1 dan 2, Tabel
1). Pada awal penurunan suhu $\left(27-21^{\circ} \mathrm{C}\right)$ cenderung terjadi peningkatan metabolisme $\left(\mathrm{NH}_{3}\right.$ dan $\mathrm{NO}_{2}$ meningkat), kemudian terjadi penurunan metabolisme hingga mencapai titik terendah pada suhu $19^{\circ} \mathrm{C}$. Pada suhu di bawah $19^{\circ} \mathrm{C}$ terjadi kembali peningkatan aktivitas metabolisme hingga suhu sekitar $15^{\circ} \mathrm{C}$ yang kemudian terjadi penurunan metabolisme yang cukup tajam.

Ketika terjadi penurunan suhu dari $27^{\circ} \mathrm{C}$ menjadi $21^{\circ} \mathrm{C}$ produksi metabolit hasil metabolisme ikan kerapu justru meningkat yang berarti metabolismenya pun meningkat. Peningkatan metabolisme ini tampaknya berkaitan erat dengan terjadinya aktivasi respirasi sehingga metabolisme dan respirasi pun meningkat. Sementara aktivitas ikan relatif tidak berubah. Tampaknya, penurunan suhu hingga $21^{\circ} \mathrm{C}$ belum mampu menekan metabolisme ikan kerapu, tetapi justru menjadi faktor penyebab aktivasi seperti yang terjadi pada respirasi.

Kemampuan penurunan suhu untuk menekan metabolisme (Fry and Norris, 1962; Huet, 1972; Jhingran and Pullin, 1985;

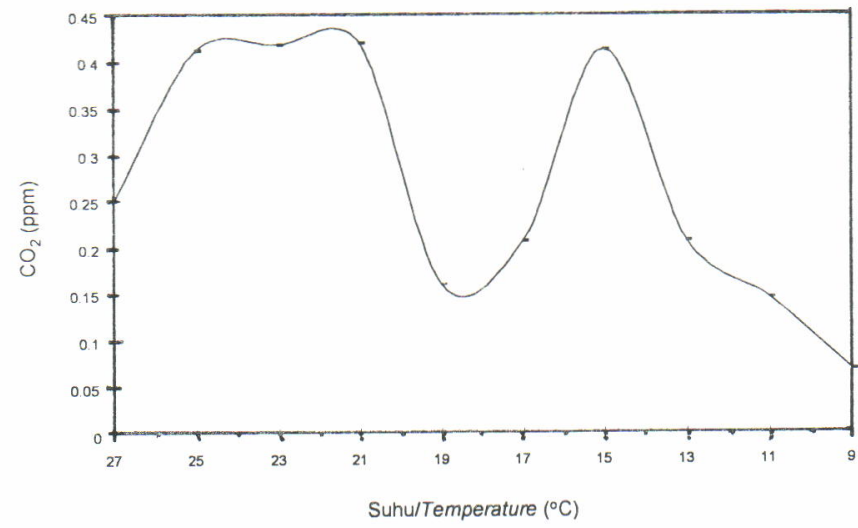

Gambar 2. Pola produksi $\mathrm{CO}_{2}$ hasil respirasi ikan kerapu hidup pada berbagai suhu

Figure 2. $\mathrm{CO}_{2}$ production pattern of grouper during respiration at various temperatures

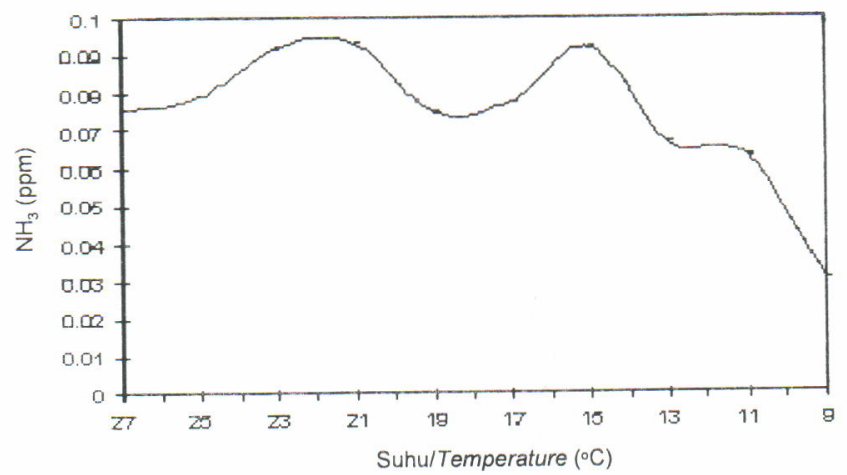

Gambar 3. Pola produksi $\mathrm{NH}_{3}$ hasil metabolisme ikan kerapu hidup pada berbagai suhu Figure 3. $\mathrm{NH}_{3}$ production pattern of grouper during metabolism at various temperatures 


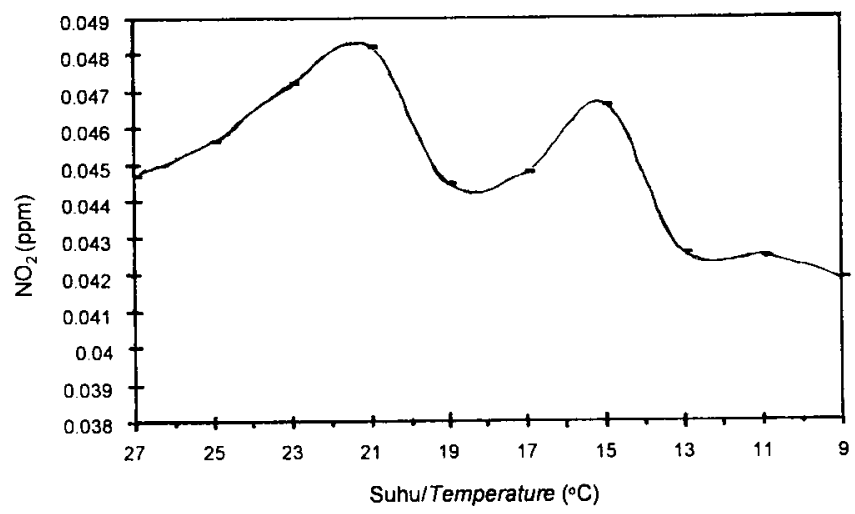

Gambar 4. Pola produksi $\mathrm{NO}_{2}$ hasil metabolisme ikan kerapu hidup pada berbagai suhu Figure 4. $\mathrm{NO}_{2}$ production pattern of grouper during metabolism at various temperatures

Suseno, 1985; Berka, 1986; Basyarie, 1990; Muchari, 1990; Praseno, 1990) mulai tampak setelah suhu berada di bawah $21^{\circ} \mathrm{C}$ hingga suhu mencapai $19^{\circ} \mathrm{C}$. Hal ini tampaknya erat kaitannya dengan adanya penurunan respirasi dan aktivitas ikan kerapu (Tabel 1, Gambar 1 dan 2). Adanya peningkatan aktivitas ikan kerapu yang berlangsung ketika ikan gelisah dan panik (pada suhu $19^{\circ} \mathrm{C}-15^{\circ} \mathrm{C}$ ) selain meningkatkan respirasi juga menyebabkan peningkatan metabolisme. Melemahnya aktivitas ikan, pada suhu di bawah $15^{\circ} \mathrm{C}$ yang mengakibatkan ikan menjadi roboh dan akhirnya pingsan, juga menyebabkan penurunan metabolisme yang tajam sebagaimana yang terjadi pada respirasi. Berdasarkan hasil di atas, tampaknya terdapat titik-titik kritis saat terjadi perubahan metabolisme yang mencolok, yaitu terjadi pada suhu $21^{\circ}, 19^{\circ}, 17-15^{\circ}$, $13^{\circ}-11^{\circ}$, yang ternyata tidak berbeda dengan titik krusial aktivitas dan respirasinya.

\section{KESIMPULAN}

1. Respon ikan kerapu lumpur terhadap suhu lingkungan yang makin rendah berlangsung dalam beberapa fase, yaitu fase normal (hingga suhu $21^{\circ} \mathrm{C}$ ) fase awal tenang (21$\left.19^{\circ} \mathrm{C}\right)$, fase tenang $\left(19^{\circ}-17^{\circ} \mathrm{C}\right)$, fase aktivitasi atau awal kegelisahan $\left(16-15^{\circ} \mathrm{C}\right)$, fase panik $\left(14.8-14^{\circ} \mathrm{C}\right)$, fase kehilangan keseimbangan atau awal disorientasi $\left(14^{\circ}\right.$ $\left.11^{\circ} \mathrm{C}\right)$, fase awal pingsan $\left(11^{\circ}-9^{\circ} \mathrm{C}\right)$, dan fase pingsan $\left(<8,8^{\circ} \mathrm{C}\right)$

2. Pola respirasi dan metabolisme ikan kerapu lumpur cenderung makin rendah dengan makin rendahnya suhu. Pada awal penurunan suhu terjadi aktivasi respirasi dan metabolisme (hingga suhu $21^{\circ} \mathrm{C}$ ) dan diikuti dengan penurunan respirasi dan metabolisme yang tajam (hingga suhu $19^{\circ} \mathrm{C}$ ). Respirasi dan metabolisme meningkat kembali bersamaan berlangsungnya fase kepanikan $\left(15^{\circ} \mathrm{C}\right)$ respirasi kemudian terus menurun.

3. Titik-titik kritis ikan kerapu berlangsung pada suhu $21^{\circ}, 19^{\circ}, 17^{\circ}, 15^{\circ}, 14^{\circ}, 11^{\circ}$. Di antara titik-titik suhu tersebut suhu $21^{\circ}, 19^{\circ}$, $17^{\circ} \mathrm{C}$ berpeluang untuk digunakan dalam transportasi sistem basah.

4. Perlu dikaji lebih lanjut pola pendekatan menggunakan sifat fisiologis ikan pada suhu rendah, untuk mengembangkan transportasi ikan kerapu hidup baik dengan sistem basah maupun sistem kering.

\section{DAFTAR PUSTAKA}

Basyarie, A. 1990. Transportasi Ikan Hidup. Makalah disampaikan pada Training Penangkapan, Aklimatisasi dan Transportasi Ikan Hias Laut, Jakarta , 4-18 Desember 1990. $15 \mathrm{p}$.

Berka, R. 1986. The Transport of Live Fish. A Review. EIFAC Tech. Pap., FAO. (48): 52

Chua, T.E and Teng S.K. 1980. Economic Production of Estuary Grouper, Epinephelus salmooides Maxwell, Reared in Floating Netcages. Aquaculture, 20:187-228.

Djajadipoera, B.S. 1988. Efektivitas Minyak Cengkeh dalam Pengangkutan Ikan Nila (Sarotherodon niloticus T.) Karya IImiah. Fakultas Perikanan, Institut Pertanian Bogor, Bogor. $42 \mathrm{p}$.

Fry, F.E. and Norris K.S. 1962. The transportation of live fish. In Borgstrom G. (ed). Fish as Food Vol. Il. Academic Press, New York p. 595-608. 
Huet, M. 1972. Text Book of Fish Culture, Breeding and Cultivation of Fish. Section IV. Transport of fish. Phoenix Press inc. Quezon City, Phillipines. $436 p$.

Jhingran, V.G. and Pullin, R.S.V. 1985. A Hatchery Manual for the Common Carp. Chinese, and Indian Major Carps. ICLARM Studies and Reviews 11. Asian Development Bank p.74-80.

Muchari, 1990. Faktor-Faktor Penting yang Harus Dipertimbangkan dalam Melaksanakan Aklimatisasi. Sub Balidita Bojonegara, Serang. $12 p$.

Pawiro, S. 1999. Trend in Major Asian Markets for Live Grouper. Infofish International 4:20-28

Praseno, O. 1990. Cara Pengiriman/Transportasi Ikan dalam Keadaan Hidup. Makalah disampaikan pada Temu Aplikasi Teknologi Pertanian Departemen Pertanian Jakarta. 16 p.

Soekarto, T.S. dan Wibowo, S. 1993. Cara penanganan udang hidup di luar air untuk transportasi tujuan ekspor. Disampaikan dalam Seminar Hasil Penelitian dan Keragaan
Kegiatan Penelitian di Bogor, 8-9 Pebruari 1993, IPB, Bogor. 19 p.

Suparno, Basmal, J., Muljanah, I., dan Wibowo, S. 1994. Pengaruh suhu dan waktu pembiusan dengan pendinginan bertahap terhadap ketahanan hidup udang windu tambak (Penaeus monodon Fab.). Jurnal Penelitian Pasca Panen Perikanan, (79): 73-88.

Suseno, D. 1985. Teknik Penanganan Transportasi Ikan Hidup. Pusdiklatluh Pertanian Ciawi, Bogor. 12 p.

Wibowo, S. 1993. Penerapan Teknologi Penanganan dan Transportasi Ikan Hidup di Indonesia. Disajikan dalam Diskusi Penanganan dan Transportasi Hasil Perikanan Hidup di IPB, September 1993. 16 p.

Wibowo, S.; Setiabudi E., dan Suparno 1995. Transportasi sistem kering udang windu tambak (Penaeus monodon) untuk ekspor. Disajikan dalam: Review dan Analisis Hasil Penelitian ARMP, 11 April 1995, di Cisarua, Bogor. 15 p. 
